(1-2 min. on the source after $2 \mathrm{hr}$. fasting, $24 \mathrm{hr}$. on test plants, 10 aphids a plant). Mosaic was obtained on young leaves within 10-20 days.

The virus was transmitted from infected beet to chickweed seedlings in the same conditions by Myzus persicae. It was then re-transmitted from supposed infected Stellaria to beet seedlings by Myzus ascalonicus Doncaster (1-2 min. on the source, after $2 \mathrm{hr}$. fasting; ten aphids a plant; $24 \mathrm{hr}$. on beet). Two of the five tested plants showed mosaic on young leaves after 15-20 days.

According to preliminary results, beet mosaic is also transmissible from infected Capsella bursapastoris to beet by Myzus ascalonicus.

Using beet as a source, Myzus ascalonicus was not considered previously as a vector of beet mosaic virus ${ }^{1}$. The results of our trials show that this aphid is able to transmit the virus from infected Stellaria media growing in the field, and from artificially infected Stellaria and Capsella bursa-pastoris. So far as we know, these two weeds seem to be now hosts of the virus.

Myzus ascalonicus is known from the literature as a vector of beet yellows (Beta virus 4 Roland and Quanjer), and Stellaria media as a host of this virus. Although the transmission of beet yellows from chickweed in the field by Myzus ascalonicus has not yet been found with certainty in our trials, the first results indicate that it is most probable.

I should like to thank Dr. Roland, director of the Phytovirology Laboratory, for advice and criticism during this work.

This work was subsidized by the Institute for Scientific Research in Industry and Agriculture.

Phytovirology Laboratory, J. Semat Gembloux, Belgium.

Doncaster and Kassanis, Ann. App. Biol., 33, 66 (1946).

\section{Effect of Herbicide 2,4-D on Bean Chocolate-Spot Disease}

THE herbicide 2,4-D (2,4 dichlorophenoxyacetic acid) has been recorded to affect fungal-host relationship. Ibrahim ${ }^{1}$ demonstrated a reduction in the number of rust uredosori to one-fifth on treated oat plants compared with controls. Similarly, Crowdy and Wain ${ }^{2}$ recorded a suppression in bean chocolatespot disease treated with $2,4,6$ trichlorophenoxyacetic acid. On the other hand, wheat plants treated with 2,4-D were found to be weakened, stunted and predisposed to a heavier infection with Helminthosporium sativum $^{3}$. 2,4-D has been recorded to cause a depletion in the carbohydrate content of treated plants ${ }^{4,5}$; Weller and co-workers ${ }^{6}$ observed a depletion of non-reducing sugars.

The present work aims at an evaluation of the possible role of $2,4-\mathrm{D}$ in influencing the relationship between bean plants (Vicia faba L., Breed No. 34) and Botrytis fabae and the interpretation of such an effect in terms of: (a) pathological anatomy of infected treated and untreated plants; (b) fungal enzymic activity as influenced by host metabolism in absence or presence of $2,4-\mathrm{D}$; (c) host biochemical changes, in response to 2,4-D treatment, and their possible bearing on fungal development.

Leaflets of bean cut shoots, previously dipped for five days in pure water or in aqueous solution of 5 p.p.m. 2,4-D sodium salt, or freshly cut, were
Table 1. Phrcentagk Lear-ARea Infection aNd Carbohydrate ANALYSIS (GM. PER 100 GM. DRY WRTGHT) OF LEAFLATS FROM DIF-

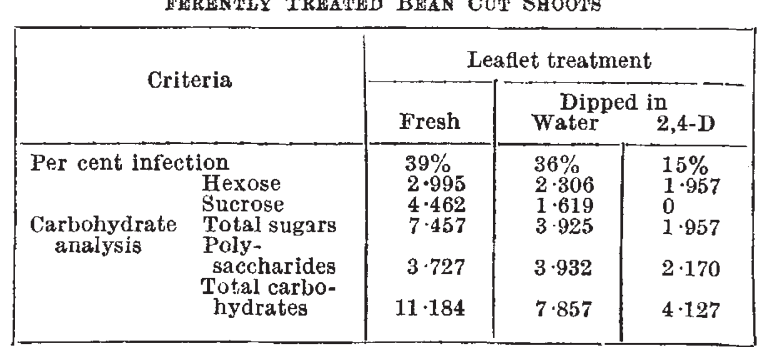

sprayed evenly with a spore suspension of Botrytis fabae to ensure a film of suspension on both leaflet surfaces; similarly, treated cut shoots were left uninoculated to serve as controls. For each treat. ment, three plants were used; they were kept constantly under humid conditions. The disease criteria were measured on leaves (Nos. 4, 5, 6 and 7), $48 \mathrm{hr}$. after spraying, by a method adopted by Crowdy and Wain ${ }^{2}$. The number of lesions, on both surfaces of the leaflet, was calculated and the mean diameter of a large number of lesions was determined. Since the lesions are more or less circular in outline, the mean area of the infected lesions could be calculated from the formula $\left(\pi r^{2}\right)$. The total infected area was afterwards obtained by multiplying the mean area of the lesions on both surfaces of each experimental leaflet; percentage infection could be thus represented as percentage ratio between total infected area and total area of both leaflet surfaces; the latter was determined by planimeter. The results (Table 1) indicated a considerable reduction in percentage infection in cut shoots previously treated with 2,4-D in comparison with those dipped in water or previously freshly cut. In addition, carbohydrate analysis was made by Maskell's method modified by Gawadi ${ }^{7}$.

No pathological differences could be detected in the anatomy of infected leaflets under varying treatments. The fungal enzymic activity, as influenced by the 2,4-D treatment of bean leaflets, was tested by Brown's disk method, as follows: juices were squeezed from differently treated cut shoots, cold sterilized by Menon's technique ${ }^{8}$, inoculated heavily with Botrytis spores and incubated for three days at $25^{\circ} \mathrm{C}$. The reaction times for Botrytis macerating enzymes, obtained from differently treated juices, were found to be close (that is, ranging between 18 and $20 \mathrm{hr}$.), denoting a feeble enzymic activity. On the other hand, the herbicidal treatment results in a depletion in the carbohydrate content of the leaf, especially sucrose, which completely disappears; such depletion may interfere with the normal development and pathogenic potentiality of Botrytis.

M. A. Mostafa

Botany Department,

S. K. GAYED

University of Cairo, Giza.

July 8.

1 Ibrahim, I. A., Phytopath., 41, 951 (1951).

${ }^{2}$ Crowdy, S. H., and Wain, R. I., Ann. App. Biol., 38, 318 (1951),

${ }^{2}$ Hsia, Y. T., and Christensen. J. J., Phytopath., 41, 1011 (1951).

- Mitchell, J. V., and Brown, J. W., Bot. Gaz., 107, 120 (1945).

5 Wort, D. J., Amer. J. Bot., 36, 673 (1949).

-Weller, L. E., and co-workers, Plant Physiol., 50, 289 (1950).

'Gawadi, A. E., Ph.D. thesis, Cambridge (1985).

B Menon, K. P. V., Ann. Bot., 48, 187 (1934). 